\title{
Depth zonation and latitudinal distribution of deep-sea scavenging demersal fishes of the Mid-Atlantic Ridge, 42 to $53^{\circ} \mathrm{N}$
}

\author{
N. J. King*, P. M. Bagley, I. G. Priede \\ Oceanlab, University of Aberdeen, Newburgh, Aberdeenshire AB41 6AA, UK
}

\begin{abstract}
Scavenging fishes of the Mid-Atlantic Ridge (MAR) were investigated using a baited autonomous lander equipped with a time-lapse camera between 924 and $3420 \mathrm{~m}$ water depth along 3 east-west transects at 42,51 and $53^{\circ} \mathrm{N}$ across the MAR. We photographed 22 taxa at bait. Community structure analysis revealed 3 main assemblages, shallow (924 to $1198 \mathrm{~m}$ ), intermediate (1569 to $2355 \mathrm{~m}$ ) and deep (2869 to $3420 \mathrm{~m}$ ), dominated by 3 species, Synaphobranchus kaupii, Antimora rostrata and Coryphaenoides (Nematonurus) armatus, respectively. Abyssal species in the axial valley region were C. armatus, Histiobranchus bathybius and Spectrunculus sp. Compared with continental margin regions $A$. rostrata were abundant and grew to a large size in the 2 northern transects, whereas $S$. kaupii were reduced in abundance and maximum depth of occurrence. The size, abundance and depth distribution of $C$. armatus was consistent with the hypothesis that these fish are part of a population mixing freely across the deep North Atlantic Basin. Temperature and latitude influenced distribution. (1) Five taxa were found only in the southern transect: Pseudotriakis microdon, Centroscymnus coelolepis, Simenchelys parasitica, Anguilliformes sp. and Lepidion 1 sp. (guentheri?). (2) Eight taxa were confined to the 2 northern transects: Bathyraja sp., Coryphaenoides 1 sp. (leptolepis?/mediterraneus?), Coryphaenoides 2 sp. (leptolepis?/mediterraneus?), Macrourus berglax, young macrourids, Lepidion 2 spp. (schmidti?), Anarhichas denticulatus and an unidentified zoarcid (Lycodonus n. sp.?/Lycenchelys alba?). (3) Eight species were ubiquitous across all 3 transects: Etmopterus princeps, Hydrolagus affinis, H. bathybius, S. kaupii, C. armatus, A. rostrata, Lepidion eques and Spectrunculus $1 \mathrm{sp..}$
\end{abstract}

KEY WORDS: Mid-Atlantic Ridge - Depth zonation - Scavenging fish - Deep sea - Landers · Coryphaenoides (Nematonurus) armatus · Antimora rostrata · Synaphobranchus kaupii

\section{INTRODUCTION}

The Mid-Atlantic Ridge (MAR) between $40^{\circ} \mathrm{N}$ (Azores) and $63^{\circ} \mathrm{N}$ (Iceland) is the largest topographic feature in the North Atlantic Ocean. It is characterised by complex bathymetry, great distances from continental land masses and its intersection with the subpolar front, a boundary between temperate/subtropical and sub-arctic water masses (Berger 1989, Longhurst 1998). This area has been explored for commercially exploitable demersal species, mainly by the former Soviet Union (Troyanovsky \& Lisovsky 1995, Bergstad \& Godø 2002). Hareide \& Garnes (2001) surveyed demersal species down to $2000 \mathrm{~m}$ depth. They detected a faunal divide at latitudes between 48 and $52^{\circ} \mathrm{N}$, where species reach the southern or northern limits of their distributions. These fishes have received very little attention and were not covered in the 'Summary atlas of deep-living demersal fishes of the North Atlantic Basin' (Haedrich \& Merrett 1988). Classical studies along transects from the continental shelf edge, across the continental slope, down to the abyss show a succession of species with adaptations to progressively greater hydrostatic pressures, colder temperatures and a decrease in food supply (Carney 2005).

The slopes of the MAR differ from corresponding continental margin slopes in several important ways. The crest of the ridge between 42 and $53^{\circ} \mathrm{N}$ rises to ca. 
$1000 \mathrm{~m}$ depth, so the upper slope and much of the midslope depth range at which recruitment of many species occurs (Merrett \& Haedrich 1997) is absent. Organic matter input to continental margin regions is derived from lateral advection of material from coastal and shelf regions and surface productivity, whilst on the MAR input is predominantly only from the latter (van Weering et al. 1998).
Thus, in comparison with equivalent continental margin regions, we hypothesise that demersal fishes of the MAR are influenced by a truncated depth range of available habitat, as well as lower food availability. The latter suggests that if food supply influences the depth distribution of fish species, they should be displaced to shallower depths, but limited by an absolute upper barrier corresponding to the summit of the MAR.

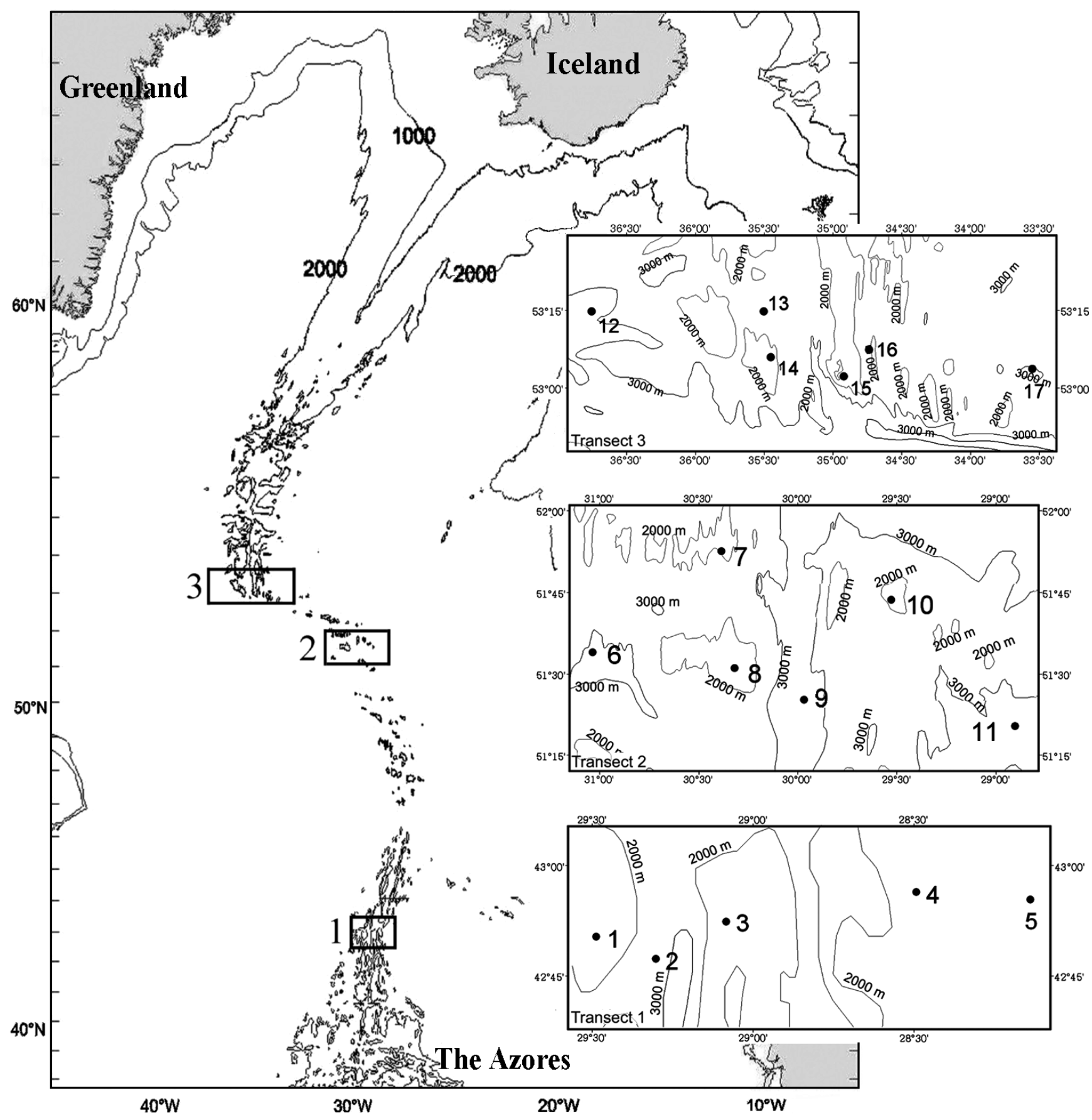

Fig. 1. Map of the study area indicating the positions of the 3 transects. Locations of each deployment are shown in the insets 
Furthermore, at the latitude of the Charlie-Gibbs Fracture Zone (CGFZ), the North Atlantic Drift traverses the MAR, therefore defining a boundary, the sub-polar front, between colder productive waters to the north and warmer lower productivity waters to the south. Henriques et al. (2002) showed that abundance of deep demersal fishes is greatly influenced by latitudinal differences in surface productivity. It is most probable that fishes of the MAR are influenced in the same way.

In the present study we used a baited free-fall lander equipped with a digital camera that could be deployed on the rough terrain of the MAR. Our objective was to: (1) catalogue the scavenging fish fauna of the MAR, (2) determine the effect of latitude in relation to the subpolar front, (3) investigate the presence of depth-specific communities and (4) estimate the abundance of species at these locations to identify potential trends in biomass. Studies were carried out at 924 to $3420 \mathrm{~m}$, and data were compared with previous studies on the continental margins of the NE Atlantic Ocean (Priede et al. 1994).

\section{MATERIALS AND METHODS}

Study region and lander operations. Data were collected from the RV 'G.O. Sars' during the second leg of the MAR-ECO (Mid-Atlantic Ridge Ecology, www. mar-eco.no) cruise to the MAR (3 July to 3 August
2004), using the RObust BIOdiversity lander (ROBIO) (Jamieson \& Bagley 2005).

The ROBIO was equipped with a downward facing digital stills camera (Kongsberg Maritime, OE14-208, 4.1 megapixel), a flash unit (Kongsberg Maritime, OE11-242), a Sensortec (UCM-60DL) current meter and a twin acoustic ballast release system (IXSEA OCEANO AR and RT). When deployed, the lander was suspended $2 \mathrm{~m}$ above the seafloor by ballast, which was in the centre of the field of view. A reference scale $(1 \mathrm{~m} \times 1 \mathrm{~m}$, cross marked at $10 \mathrm{~cm}$ intervals $)$ and $500 \mathrm{~g}$ of mackerel Scomber scombrus bait were attached to the ballast approximately 10 to $30 \mathrm{~cm}$ above the seafloor. Mackerel was used as bait for consistency with other studies. Ribbons were attached to the end of each arm of the scale cross to visually corroborate current direction. The system was recovered by release of the ballast on acoustic command.

Sampling was distributed along 3 east-west transects across the MAR (Table 1, Fig. 1) and comprised Transect 1 (5 deployments north of the Azores at $42^{\circ} \mathrm{N}$ ), Transect 2 (6 deployments southeast of the CGFZ at $51^{\circ} \mathrm{N}$ ) and Transect 3 (6 deployments northwest of the CGFZ at $53^{\circ} \mathrm{N}$ ). Depths ranged from 924 to $3420 \mathrm{~m}$.

Images were taken at $90 \mathrm{~s}$ intervals (except Deployment 1 , in which $60 \mathrm{~s}$ intervals were used), with approximately 250 images per deployment. Depth, temperature, conductivity, current velocity and direction were logged at $60 \mathrm{~s}$ intervals by the current meter.

Table 1. ROBIO (RObust BIOdiversity lander) deployment summary, Mid-Atlantic Ridge, July 2004. Current velocity data are mean $\pm \mathrm{SD}$; temperature and salinity: $\mathrm{SD} \leq 0.06$

\begin{tabular}{|c|c|c|c|c|c|c|c|c|c|}
\hline Stn & Latitude & Longitude & $\begin{array}{l}\text { Touchdown } \\
\text { time (GMT) }\end{array}$ & $\begin{array}{c}\text { Deployment } \\
\text { duration (h:min) }\end{array}$ & $\begin{array}{l}\text { Depth } \\
\text { (m) }\end{array}$ & $\begin{array}{l}\text { Current velocity } \\
\qquad\left(\mathrm{mm} \mathrm{s}^{-1}\right)\end{array}$ & $\begin{array}{l}\text { Temp. } \\
\left({ }^{\circ} \mathrm{C}\right)\end{array}$ & Salinity & $\begin{array}{l}\text { Fluorescence } \\
\quad\left(\mu \mathrm{g} \mathrm{l}^{-1}\right)\end{array}$ \\
\hline \multicolumn{10}{|c|}{ Transect $1\left(42^{\circ} \mathrm{N}\right)$} \\
\hline 1 & $42^{\circ} 50^{\prime} \mathrm{N}$ & $29^{\circ} 29^{\prime} \mathrm{W}$ & $00: 38$ & $2: 56$ & 1569 & $23.7 \pm 4.6$ & 4.7 & 34.0 & 0.12 \\
\hline 2 & $42^{\circ} 47^{\prime} \mathrm{N}$ & $29^{\circ} 18^{\prime} \mathrm{W}$ & 01:16 & $4: 42$ & 3063 & $21.8 \pm 11.3$ & 3.9 & 32.8 & 0.12 \\
\hline 3 & $42^{\circ} 52^{\prime} \mathrm{N}$ & $29^{\circ} 05^{\prime} \mathrm{W}$ & $20: 15$ & $4: 02$ & 1198 & $37.8 \pm 21.6$ & 5.6 & 33.8 & 0.11 \\
\hline 4 & $42^{\circ} 56^{\prime} \mathrm{N}$ & $28^{\circ} 30^{\prime} \mathrm{W}$ & $10: 14$ & $5: 11$ & 1934 & $39.0 \pm 17.9$ & 4.1 & 33.7 & 0.07 \\
\hline 5 & $42^{\circ} 55^{\prime} \mathrm{N}$ & $28^{\circ} 09^{\prime} \mathrm{W}$ & $11: 26$ & $3: 41$ & 2869 & $27.0 \pm 13.8$ & 3.6 & 32.9 & 0.12 \\
\hline \multicolumn{10}{|c|}{ Transect $2\left(51^{\circ} \mathrm{N}\right)$} \\
\hline 6 & $51^{\circ} 34^{\prime} \mathrm{N}$ & $31^{\circ} 02^{\prime} \mathrm{W}$ & $02: 40$ & $6: 05$ & 3346 & $29.0 \pm 6.5$ & 3.1 & 32.3 & 0.24 \\
\hline 7 & $51^{\circ} 53^{\prime} \mathrm{N}$ & $30^{\circ} 23^{\prime} \mathrm{W}$ & $19: 42$ & $4: 45$ & 1742 & $48.1 \pm 19.5$ & 3.7 & 33.5 & 0.33 \\
\hline 8 & $51^{\circ} 31^{\prime} \mathrm{N}$ & $30^{\circ} 19^{\prime} \mathrm{W}$ & $20: 23$ & $4: 12$ & 924 & $32.8 \pm 25.4$ & 4.4 & 33.3 & 0.32 \\
\hline 9 & $51^{\circ} 25^{\prime} \mathrm{N}$ & $29^{\circ} 58^{\prime} \mathrm{W}$ & $20: 49$ & $5: 15$ & 3420 & $39.8 \pm 24.2$ & 3.3 & 32.0 & 0.3 \\
\hline 10 & $51^{\circ} 44^{\prime} \mathrm{N}$ & $29^{\circ} 31^{\prime} \mathrm{W}$ & $03: 27$ & $4: 45$ & 1790 & $63.4 \pm 36.9$ & 3.7 & 33.3 & 0.32 \\
\hline 11 & $51^{\circ} 20^{\prime} \mathrm{N}$ & $28^{\circ} 54^{\prime} \mathrm{W}$ & 08:00 & $5: 38$ & 3396 & $35.7 \pm 9.9$ & 3.2 & 32.2 & 0.21 \\
\hline \multicolumn{10}{|c|}{ Transect $3\left(53^{\circ} \mathrm{N}\right)$} \\
\hline 12 & $53^{\circ} 17^{\prime} \mathrm{N}$ & $36^{\circ} 45^{\prime} \mathrm{W}$ & $23: 15$ & $6: 08$ & 2908 & $73.6 \pm 15.4$ & 3.3 & 32.6 & 0.3 \\
\hline 13 & $53^{\circ} 17^{\prime} \mathrm{N}$ & $35^{\circ} 30^{\prime} \mathrm{W}$ & 08:41 & $5: 53$ & 2355 & $30.7 \pm 7.8$ & 3.4 & 33.1 & 0.23 \\
\hline 14 & $53^{\circ} 05^{\prime} \mathrm{N}$ & $35^{\circ} 27^{\prime} \mathrm{W}$ & 01:10 & $4: 17$ & 1124 & $60.2 \pm 27.9$ & 3.8 & 33.5 & 0.2 \\
\hline 15 & $53^{\circ} 00^{\prime} \mathrm{N}$ & $34^{\circ} 55^{\prime} \mathrm{W}$ & 01:26 & $4: 53$ & 1735 & $35.7 \pm 17.9$ & 3.5 & 33.5 & 0.26 \\
\hline 16 & $53^{\circ} 07^{\prime} \mathrm{N}$ & $34^{\circ} 44^{\prime} \mathrm{W}$ & $06: 07$ & $6: 02$ & 2065 & $19.7 \pm 8.9$ & 3.4 & 33.3 & 0.18 \\
\hline 17 & $53^{\circ} 02^{\prime} \mathrm{N}$ & $33^{\circ} 33^{\prime} \mathrm{W}$ & $08: 57$ & $6: 15$ & 2934 & $27.2 \pm 9.6$ & 3.3 & 32.6 & 0.15 \\
\hline
\end{tabular}


Table 2. Scavenger taxa attracted to deployed bait. Peak abundance at bait (max. N), percentage of frames in which the taxon was visible (frames) and total length of fish (TL; mean $\pm \mathrm{SD}$ ). Taxa are arranged in order of minimum depth of occurrence, where taxa are recorded at the same minimum depth they are arranged taxonomically. For some species it was not possible to measure

TL (-), individual animals have no SD

\begin{tabular}{|c|c|c|c|c|c|c|c|}
\hline Taxon & $\begin{array}{l}\text { Depth } \\
\text { (m) }\end{array}$ & Stn & Transect & $\begin{array}{l}\text { First arrival } \\
\text { time (min) }\end{array}$ & Max. N & $\begin{array}{c}\text { Frames } \\
(\%)\end{array}$ & $\begin{array}{c}\mathrm{TL} \\
(\mathrm{mm})\end{array}$ \\
\hline \multirow[t]{5}{*}{ Etmopterus princeps } & 924 & 8 & 2 & 1.5 & 2 & 7.1 & $455 \pm 49$ \\
\hline & 1124 & 14 & 3 & 88.5 & 1 & 1.2 & - \\
\hline & 1198 & 3 & 1 & 9.0 & 1 & 2.5 & $564 \pm 72$ \\
\hline & 1569 & 1 & 1 & 5.0 & 6 & 80.8 & $517 \pm 120$ \\
\hline & 1934 & 4 & 1 & 42.0 & 2 & 5.8 & $458 \pm 146$ \\
\hline \multirow[t]{5}{*}{ Synaphobranchus kaupii } & 924 & 8 & 2 & 24.0 & 2 & 9.5 & $645 \pm 61$ \\
\hline & 1124 & 14 & 3 & 7.5 & 1 & 4.1 & $528 \pm 41$ \\
\hline & 1198 & 3 & 1 & 3.0 & 3 & 37.7 & $557 \pm 69$ \\
\hline & 1569 & 1 & 1 & 4.0 & 7 & 85.3 & $560 \pm 74$ \\
\hline & 1934 & 4 & 1 & 4.5 & 4 & 39.4 & $529 \pm 69$ \\
\hline \multirow[t]{3}{*}{ Lepidion eques } & 924 & 8 & 2 & 12.0 & 3 & 21.3 & $272 \pm 51$ \\
\hline & 1124 & 14 & 3 & 151.5 & 1 & 0.6 & 326 \\
\hline & 1198 & 3 & 1 & 3.0 & 2 & 3.1 & $564 \pm 72$ \\
\hline \multirow[t]{8}{*}{ Antimora rostrata } & 924 & 8 & 2 & 22.5 & 1 & 4.1 & $484 \pm 68$ \\
\hline & 1124 & 14 & 3 & 0.0 & 8 & 56.4 & $517 \pm 84$ \\
\hline & 1735 & 15 & 3 & 3.0 & 10 & 44.4 & $533 \pm 55$ \\
\hline & 1742 & 7 & 2 & 12.0 & 9 & 31.9 & $484 \pm 78$ \\
\hline & 1790 & 10 & 2 & 1.5 & 7 & 25.1 & $584 \pm 95$ \\
\hline & 1934 & 4 & 1 & 6.0 & 3 & 23.1 & $526 \pm 79$ \\
\hline & 2065 & 16 & 3 & 6.0 & 7 & 52.1 & $446 \pm 69$ \\
\hline & 2355 & 13 & 3 & 1.5 & 13 & 45.3 & $500 \pm 51$ \\
\hline \multirow[t]{2}{*}{ Macrourus berglax } & 924 & 8 & 2 & 10.5 & 1 & 1.8 & 486 \\
\hline & 1124 & 14 & 3 & 4.5 & 2 & 8.7 & $480 \pm 48$ \\
\hline \multirow{2}{*}{ Anarhichas denticulatus } & 924 & 8 & 2 & 12.0 & 2 & 31.4 & $1062 \pm 110$ \\
\hline & 1124 & 14 & 3 & 256.5 & 1 & 0.6 & - \\
\hline \multirow[t]{7}{*}{ Hydrolagus affinis } & 1124 & 14 & 3 & 100.5 & 1 & 2.3 & 1113 \\
\hline & 1735 & 15 & 3 & 63.0 & 1 & 3.6 & - \\
\hline & 1742 & 7 & 2 & 48.0 & 2 & 17.3 & $933 \pm 274$ \\
\hline & 1790 & 10 & 2 & 4.5 & 2 & 19.4 & $1072 \pm 284$ \\
\hline & 1934 & 4 & 1 & 172.5 & 1 & 4.8 & $945 \pm 95$ \\
\hline & 2065 & 16 & 3 & 327.0 & 1 & 0.8 & - \\
\hline & 2355 & 13 & 3 & 63.0 & 1 & 1.7 & 1175 \\
\hline Pseudotriakis microdon & 1198 & 3 & 1 & 129.0 & 1 & 2.5 & - \\
\hline \multirow[t]{3}{*}{ Centroscymnus coelolepis } & 1198 & 3 & 1 & 55.5 & 1 & 2.5 & 762 \\
\hline & 1569 & 1 & 1 & 12.0 & 1 & 11.9 & $898 \pm 49$ \\
\hline & 1934 & 4 & 1 & 25.5 & 2 & 18.3 & $934 \pm 67$ \\
\hline \multirow[t]{2}{*}{ Anguilliformes sp. } & 1198 & 3 & 1 & 177.0 & 1 & 3.0 & $99 \pm 41$ \\
\hline & 1569 & 1 & 1 & 55.0 & 4 & 19.8 & $111 \pm 32$ \\
\hline Lepidion $1 \mathrm{sp}$. & 1198 & 3 & 1 & 15.0 & 1 & 6.8 & 646 \\
\hline \multirow[t]{2}{*}{ Simenchelys parasitica } & 1569 & 1 & 1 & 126.0 & 1 & 2.8 & $264 \pm 11$ \\
\hline & 1934 & 4 & 1 & 118.5 & 1 & 0.5 & - \\
\hline \multirow[t]{10}{*}{ Coryphaenoides (Nematonurus) armatus } & 1735 & 15 & 3 & 67.5 & 1 & 0.5 & 299 \\
\hline & 2065 & 16 & 3 & 63.0 & 5 & 50.8 & $412 \pm 59$ \\
\hline & 2355 & 13 & 3 & 22.5 & 7 & 50.4 & $439 \pm 91$ \\
\hline & 2869 & 5 & 1 & 18.0 & 11 & 85.1 & $521 \pm 74$ \\
\hline & 2908 & 12 & 3 & 13.5 & 17 & 85.8 & $507 \pm 78$ \\
\hline & 2934 & 17 & 3 & 6.0 & 15 & 75.7 & $468 \pm 86$ \\
\hline & 3063 & 2 & 1 & 51.0 & 5 & 46.0 & $621 \pm 99$ \\
\hline & 3346 & 6 & 2 & 12.0 & 17 & 62.7 & $490 \pm 89$ \\
\hline & 3396 & 11 & 2 & 81.0 & 7 & 57.5 & $596 \pm 145$ \\
\hline & 3420 & 9 & 2 & 24.0 & 6 & 30.2 & $536 \pm 132$ \\
\hline \multirow[t]{3}{*}{ Coryphaenoides 1 sp. } & 1124 & 14 & 3 & 159.0 & 1 & 0.6 & 568 \\
\hline & 1735 & 15 & 3 & 15.0 & 1 & 6.6 & $506 \pm 52$ \\
\hline & 2355 & 13 & 3 & 12.0 & 1 & 1.7 & $508 \pm 35$ \\
\hline
\end{tabular}


Table 2 (continued)

\begin{tabular}{|c|c|c|c|c|c|c|c|}
\hline Taxon & $\begin{array}{l}\text { Depth } \\
\text { (m) }\end{array}$ & Stn & Transect & $\begin{array}{l}\text { First arrival } \\
\text { time (min) }\end{array}$ & Max. N & $\begin{array}{c}\text { Frames } \\
(\%)\end{array}$ & $\begin{array}{c}\mathrm{TL} \\
(\mathrm{mm})\end{array}$ \\
\hline Young Macrouridae & $\begin{array}{l}1735 \\
2355 \\
2908 \\
2934\end{array}$ & $\begin{array}{l}15 \\
13 \\
12 \\
17\end{array}$ & $\begin{array}{l}3 \\
3 \\
3 \\
3\end{array}$ & $\begin{array}{r}108.0 \\
12.0 \\
63.0 \\
9.0\end{array}$ & $\begin{array}{l}2 \\
1 \\
1 \\
1\end{array}$ & $\begin{array}{l}1.5 \\
2.1 \\
1.2 \\
0.8\end{array}$ & $\begin{array}{c}107 \pm 14 \\
99 \pm 29 \\
49 \\
113 \pm 6\end{array}$ \\
\hline Spectrunculus $2 \mathrm{sp}$. & $\begin{array}{l}1735 \\
1934 \\
2065 \\
3063 \\
3420\end{array}$ & $\begin{array}{r}15 \\
4 \\
16 \\
2 \\
9\end{array}$ & $\begin{array}{l}3 \\
1 \\
3 \\
1 \\
2\end{array}$ & $\begin{array}{r}34.5 \\
70.5 \\
123.0 \\
106.5 \\
22.5\end{array}$ & $\begin{array}{l}1 \\
1 \\
1 \\
3 \\
4\end{array}$ & $\begin{array}{c}1.5 \\
13.9 \\
0.4 \\
32.8 \\
75.8\end{array}$ & $\begin{aligned}- & - \\
453 & \pm 78 \\
& - \\
230 & \pm 33 \\
283 & \pm 44\end{aligned}$ \\
\hline Lepidion $2 \mathrm{sp}$. & 1790 & 10 & 2 & 133.5 & 1 & 2.1 & 709 \\
\hline Bathyraja sp. & $\begin{array}{l}2065 \\
2355 \\
2908 \\
3396\end{array}$ & $\begin{array}{l}16 \\
13 \\
12 \\
11\end{array}$ & $\begin{array}{l}3 \\
3 \\
3 \\
2\end{array}$ & $\begin{array}{r}249.0 \\
202.5 \\
175.5 \\
34.5\end{array}$ & $\begin{array}{l}1 \\
1 \\
1 \\
1\end{array}$ & $\begin{array}{l}0.4 \\
4.7 \\
0.4 \\
4.4\end{array}$ & $\begin{aligned} & - \\
1326 & \pm 219 \\
& - \\
& -\end{aligned}$ \\
\hline Spectrunculus $1 \mathrm{sp}$. & $\begin{array}{l}2355 \\
2869 \\
2908\end{array}$ & $\begin{array}{r}13 \\
5 \\
12\end{array}$ & $\begin{array}{l}3 \\
1 \\
3\end{array}$ & $\begin{array}{r}216.0 \\
163.5 \\
64.5\end{array}$ & $\begin{array}{l}1 \\
1 \\
1\end{array}$ & $\begin{array}{c}1.3 \\
15.0 \\
8.9\end{array}$ & $\begin{array}{c}- \\
1188 \pm 137 \\
-\end{array}$ \\
\hline Histiobranchus bathybius & $\begin{array}{l}2869 \\
2908 \\
2934 \\
3063 \\
3346 \\
3396 \\
3420\end{array}$ & $\begin{array}{r}5 \\
12 \\
17 \\
2 \\
6 \\
11 \\
9\end{array}$ & $\begin{array}{l}1 \\
3 \\
3 \\
1 \\
2 \\
2 \\
2\end{array}$ & $\begin{array}{r}63.0 \\
12.0 \\
15.0 \\
30.0 \\
31.5 \\
7.5 \\
45.0\end{array}$ & $\begin{array}{l}2 \\
2 \\
4 \\
2 \\
2 \\
1 \\
1\end{array}$ & $\begin{array}{c}16.2 \\
22.0 \\
21.5 \\
18.5 \\
23.8 \\
4.9 \\
5.7\end{array}$ & $\begin{aligned} 725 & \pm 54 \\
707 & \pm 62 \\
93 & \pm 71 \\
638 & \pm 35 \\
676 & \pm 92 \\
783 & \pm 110 \\
794 & \pm 60\end{aligned}$ \\
\hline Zoarcidae sp. & 2934 & 17 & 3 & 282.0 & 1 & 19.1 & 267 \\
\hline Coryphaenoides $2 \mathrm{sp}$. & 3396 & 11 & 2 & 123.0 & 1 & 2.7 & $357 \pm 18$ \\
\hline
\end{tabular}

Arrival times, maximum number of fish present in the field of view, percentage of frames with visible fish and total length of fish were recorded for each species (Table 2).

Fishes were identified to the lowest possible taxonomic level using morphological characteristics visible in the images. Voucher specimens caught at each station depth using the Campeln 1800 trawl system were used to verify identification.

Abundance estimation. Estimated abundances of Synaphobranchus kaupii Johnson, 1862; Antimora rostrata (Günther, 1878); and Coryphaenoides armatus (Hector, 1875) were calculated using the methodology of Priede et al. (1990). We assumed swimming velocities of $0.077 \mathrm{~m} \mathrm{~s}^{-1}$ for $C$. armatus (Henriques et al. 2002) and $0.213 \mathrm{~m} \mathrm{~s}^{-1}$ for A. rostrata (Collins et al. 1999). For $S$. kaupii, $0.169 \mathrm{~m} \mathrm{~s}^{-1}$ was calculated from swimming speed in body lengths per second (Uiblein et al. 2002) and mean length of S. kaupii in the North Atlantic (M. A. Collins unpubl. data). Water velocity was taken as the mean current velocity in the first $30 \mathrm{~min}$ of deployment $\left(\mathrm{m} \mathrm{s}^{-1}\right)$.

Coryphaenoides armatus were observed most often (10 deployments) and could therefore be analysed in more detail than the other species. The maximum number of fishes visible every 9 min was recorded, and a curve was fitted to this data using the model proposed by Priede et al. (1990). Best fits for curve parameters were then used for comparison between regions, with $\alpha_{0}=$ initial arrival rate (fish $\mathrm{min}^{-1}$ ) and $\beta=$ mean staying time of the fish ( $\mathrm{min}$ ).

Length measurement. Total lengths of fish were taken from images using Image Pro Plus (MediaCybernetics, Version 4.5), and linear regressions were fitted. The software was calibrated at the beginning of each deployment using the reference scale. Fish were only measured if the full length of the body was visible at an elevation equal to or lower than the reference scale. Repeat measures of the same fish in consecutive images were avoided.

Mean lengths were converted to wet weight for Coryphaenoides armatus by: $W=4 \times 10^{-10} \times L_{\text {total }}^{3.3762}$ (D. Bailey unpubl. data); for Antimora rostrata by: $L_{\text {stand }}=0.92 L_{\text {total }}-0.74, \log _{10} W=\log _{10} L_{\text {stand }}-$ 1.831/0.279 (Wenner \& Musick 1977); and for Synaphobranchus kaupii by: $W=0.000077 L_{\text {stand }}{ }^{3.6349}$. Total length was converted to standard length by subtracting $3 \%$ (Gordon \& Duncan 1987, Priede et al. 1994).

Statistical analyses. Maximum fish numbers at bait for each species were $\sqrt{ }$-transformed for community structure analysis using PRIMER 5 software (Clarke \& Warwick 1994, Clarke \& Gorley 2001). V-transforma- 


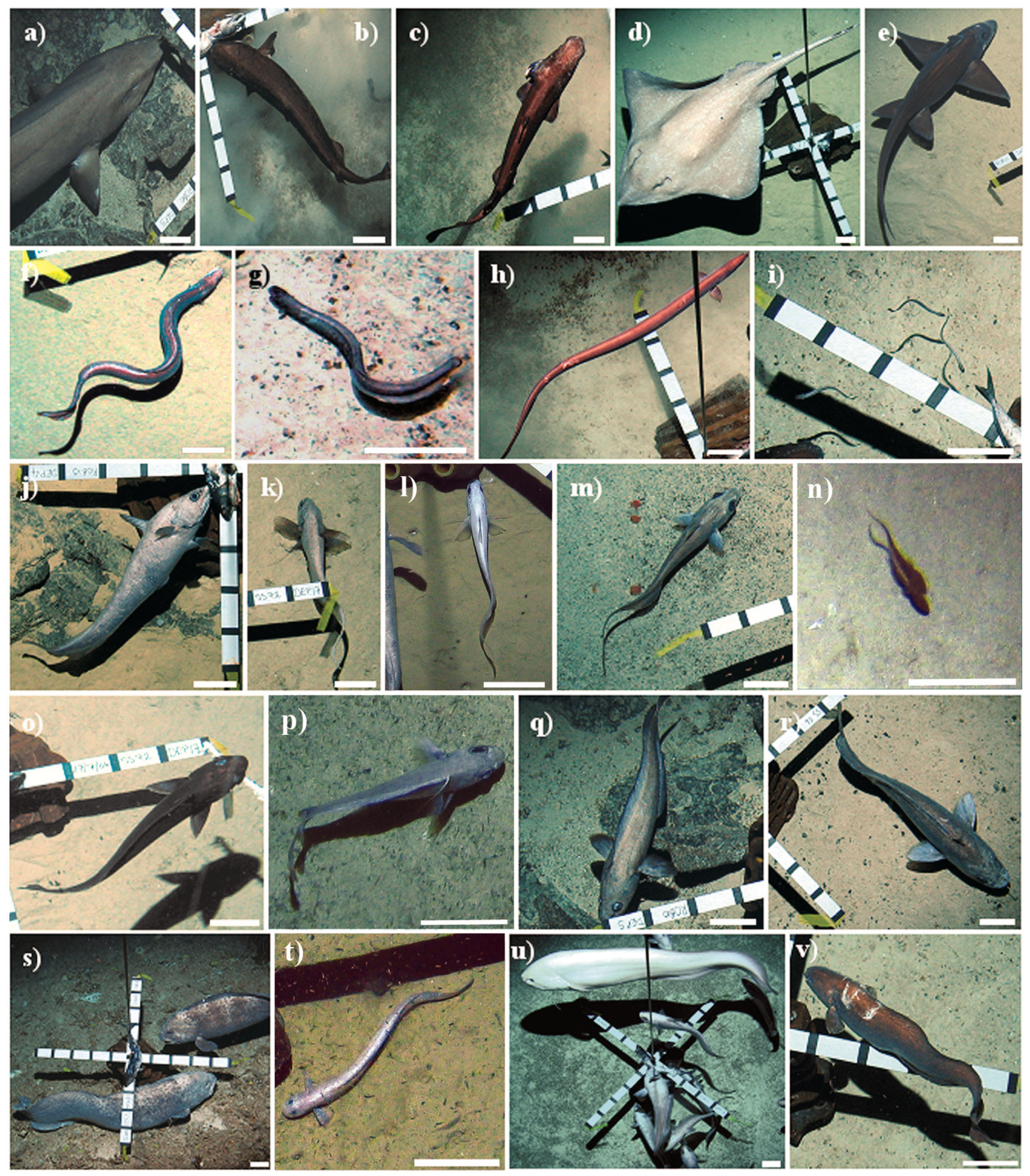

Fig. 2. Fish fauna observed at the ROBIO lander (white scale bars: $10 \mathrm{~cm}$ ): (a) Pseudotriakis microdon, $1198 \mathrm{~m}$; (b) Centroscymnus coelolepis, 1569 m; (c) Etmopterus princeps with cirripede parasite, 1569 m; (d) Bathyraja sp. (richardsoni?), 2355 m; (e) Hydrolagus affinis, 2355 m; (f) Histiobranchus bathybius, 2934 m; (g) Simenchelys parasitica, 1569 m; (h) Synaphobranchus kaupii, 1569 m; (i) unidentified anguilliformes, 1569 m; (j) Coryphaenoides (Nematonurus) armatus, 3063 m; (k) Coryphaenoides 1 sp. (leptolepis?/mediterraneus?), 2355 m; (l) Coryphaenoides 2 spp. (leptolepis?/mediterraneus?), 3396 m; (m) Macrourus berglax, 1124 m; (n) young macrourid, 2355 m; (o) Antimora rostrata with mackerel (bait) spine, 2355 m; (p) Lepidion eques, 1124 m; (q) Lepidion 1 sp. (guentheri?), 1198 m; (r) Lepidion 2 spp. (schmidti?), 1790 m; (s) Anarhichas denticulatus, 924 m; (t) unidentified Zoarcidae (Lycodonus n. sp.?/Lycenchelys alba?; P. R. Møller pers. comm.), 2934 m; (u) Large Spectrunculus 1 sp. (top) with 7 small C. armatus (foreground and bottom), 2869 m; (v) Spectrunculus 2 sp., $1934 \mathrm{~m}$ 
tion was used to allow for low abundances and rare species occurrences. Group average cluster analysis was conducted on Bray-Curtis similarities (Bray \& Curtis 1957). Non-metric, multi-dimensional scaling (nMDS) ordination was applied to visualise clusters in 2 dimensions, followed by SIMPER analysis to identify characteristic species and ANOSIM to assess the significance of the chosen level of separation between clusters.

The biota and environment matching (BIOENV) procedure was used to match biotic patterns with the abiotic environmental variables depth (m), temperature $\left({ }^{\circ} \mathrm{C}\right)$, latitude (degrees), current velocity $\left(\mathrm{mm} \mathrm{s}^{-1}\right)$ and mean fluorescence of chlorophyll a $\left(\mu \mathrm{g}^{-1}\right.$, from the top $300 \mathrm{~m}$ of the surface waters). Fluorescence data were obtained from CTD profiles obtained close to the deployment site, and were used as a proxy for primary productivity. All other environmental data were obtained from the current meter. Group cluster similarities were conducted on normalised Euclidean distances, with no transformation or standardisation.

\section{RESULTS}

\section{Diversity and community structure}

A total of 22 fish taxa (Fig. 2, Table 2) were recorded: 14 in Transect $1\left(42^{\circ} \mathrm{N}\right), 13$ in Transect $2\left(51^{\circ} \mathrm{N}\right)$ and 15 in Transect $3\left(52^{\circ} \mathrm{N}\right)$. Mean $( \pm \mathrm{SE})$ species richness per deployment differed between transects, with 5.0 $( \pm 0.89)$ in Transect $1,3.3( \pm 0.67)$ in Transect 2 and 5.8 $( \pm 0.66)$ in Transect 3 .

Eight species common to all the transects: the shark Etmopterus princeps Collett, 1904; the holocephalan Hydrolagus affinis (Capello, 1868); and the teleosts Histiobranchus bathybius (Günther, 1877), Synaphobranchus kaupii, Coryphaenoides armatus, Antimora rostrata, Lepidion eques (Günther, 1887) and Spectrunculus sp. 2. Spectrunculus sp. 1 and Spectrunculus sp. 2 were classified as Spectrunculus grandis, but represent 2 species (P. R. Møller pers. comm.).

Five species were unique to the southern transect at $42^{\circ} \mathrm{N}$ : Pseudotriakis microdon Capello, 1867; Centroscymnus coelolepis Bocage \& Capello, 1864; Simenchelys parasitica Gill, 1879; Anguilliformes sp.; and Lepidion $1 \mathrm{sp}$. (guentheri?). Of these, 8 were confined to the 2 northern transects at 51 and $53^{\circ} \mathrm{N}$ : Bathyraja sp.; Coryphaenoides 1 sp.; Coryphaenoides 2 spp.; Macrourus berglax Lacapede, 1801; young macrourids Lepidion 2 sp. (schmidti?); Anarhichas denticulatus Krøyer, 1845; and a zoarcid (Lycodonus n. sp. or Lycenchelys alba; P. R. Møller pers. comm.).

Cluster analysis revealed 5 distinct groupings, which segregated into 3 different depth bandings (Fig. 3): shallow (924 to $1198 \mathrm{~m}$ ), intermediate (1569 to $2355 \mathrm{~m}$ ) and deep (2869 to $3420 \mathrm{~m}$ ). The assemblages within the shallow and intermediate depth bands were numerically dominated in the south by Synaphobranchus kaupii and in the north by Antimora rostrata. Coryphaenoides armatus, irrespective of latitude, dominated the deep assemblage.

The shallow assemblage consisted of Groups 4 and 5. Group 4 was based on data from Deployment 3 in the southernmost transect, where Synaphobranchus kaupii were numerically dominant. Antimora rostrata were dominant in Group 5, where all 6 species contributed equally $(16.7 \%)$ to the within-group similarity (Deployments 8 \& 14, Transects 2 \& 3, 924 and $1124 \mathrm{~m}$ water depth, respectively).

Groups 2 and 3 comprise the intermediate assemblage. Antimora rostrata $(63.0 \%)$ were the most dominant species in Group 2 (Deployments 7, 10, 13, 15 \& 16, Transects $2 \& 3,1735$ to $2355 \mathrm{~m}$ depth), but Hydrolagus affinis $(24.3 \%)$ and Coryphaenoides armatus $(7.4 \%)$ also contribute. Synaphobranchus kaupii was the dominant species within Group 3 (Deployments 1 \& 3, 1569 and $1934 \mathrm{~m}$ depth), explaining $36.9 \%$ of the within-group similarity; the other $63.1 \%$ was explained by Etmopterus princeps (26.1\%), Centroscymnus coelolepis (18.5\%) and Simenchelys parasitica $(18.5 \%)$.

Group 1 was the largest group, consisting of 7 deployments $(2,5,6,9,11,12$ \& 17) between 2869 and $3420 \mathrm{~m}$. Two species contribute $61.0 \%$ to the withingroup similarity: Coryphaenoides armatus (64.7\%), the numerically dominant species, and Histiobranchus bathybius (29.3\%).

ANOSIM revealed significant spatial separation $(\mathrm{R}=$ 0.95, $\mathrm{p}=0.01$ ) when considering all groups. Binary

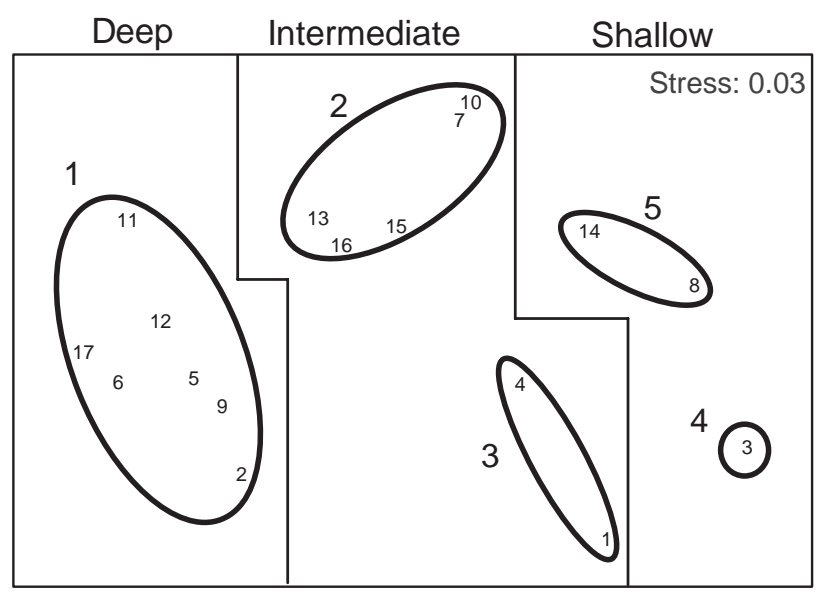

Fig. 3. MAR scavenging fish community assemblages; 2dimensional non-metric, multi-dimensional scaling configuration of $\sqrt{ }$-transformed peak abundances from Bray-Curtis similarities with 5 superimposed clusters at a similarity level of $50 \%$ 
Table 3. Synaphobranchus kaupii. Comparison of ROBIO (RObust BIOdiversity) and AUDOS (Aberdeen University Deep Ocean Submersible) lander data on the MAR (Mid-Atlantic Ridge) and PSB (Porcupine Seabight). PSB data from Priede et al. (1994). Total length data measured from photographs; wet weight calculated from applying a length-weight regression equation (see 'Materials and methods')

\begin{tabular}{|c|c|c|c|c|c|c|c|c|}
\hline Region & Deployment & $\begin{array}{l}\text { Depth } \\
\text { (m) }\end{array}$ & $\begin{array}{l}\text { First arrival } \\
\text { time (min) }\end{array}$ & $\begin{array}{l}\text { Mean total } \\
\text { length }(\mathrm{mm})\end{array}$ & $\begin{array}{l}\text { Wet weight } \\
(\mathrm{kg})\end{array}$ & $\begin{array}{l}\text { Theoretical abun- } \\
\text { dance (fish km}{ }^{-2} \text { ) }\end{array}$ & $\begin{array}{l}\text { Biomass } \\
\left(\mathrm{kg} \mathrm{km}^{-2}\right)\end{array}$ & $\begin{array}{l}\text { Peak abun- } \\
\text { dance at bait }\end{array}$ \\
\hline \multirow[t]{7}{*}{ MAR } & 1 & 1569 & 4.0 & 561 & 0.17 & 5675 & 965 & 7 \\
\hline & 3 & 1198 & 3.0 & 557 & 0.16 & 12000 & 1920 & 3 \\
\hline & 4 & 1934 & 4.5 & 529 & 0.14 & 9668 & 1354 & 4 \\
\hline & 8 & 924 & 24.0 & 645 & 0.27 & 972 & 262 & 2 \\
\hline & 14 & 1124 & 7.5 & 528 & 0.13 & 674 & 85 & 1 \\
\hline & Mean & & 9 & $552^{\mathrm{a}}$ & $0.16^{a}$ & & & \\
\hline & $\mathrm{SD}$ & & 8.77 & 72.93 & 0.08 & & & \\
\hline \multirow[t]{7}{*}{ PSB } & 47 & 755 & 2 & 257 & 0.0090 & 37040 & 333 & 3 \\
\hline & 37 & 1000 & 4 & 133 & 0.0009 & 9259 & 8 & 19 \\
\hline & 13 & 1517 & 3 & 300 & 0.0260 & 16461 & 428 & 21 \\
\hline & 9 & 1650 & 2 & 346 & 0.0370 & 37040 & 1370 & 11 \\
\hline & 16 & 2020 & 4 & 407 & 0.0570 & 9259 & 528 & 3 \\
\hline & Mean & & 3 & $255^{\mathrm{a}}$ & $0.0205^{\mathrm{a}}$ & & & \\
\hline & $\mathrm{SD}$ & & 1 & 12.30 & 0.0296 & & & \\
\hline
\end{tabular}

comparisons found significant separation $(\mathrm{p}<0.05)$ for combinations of Groups $1 \& 3,2 \& 3,1 \& 2,1 \& 5$ and 2 $\& 5$. Group 4 was not considered in the analysis. Cluster characteristics were explained best $(84.7 \%)$ by depth $(\mathrm{m})$ and temperature $\left({ }^{\circ} \mathrm{C}\right)$, and depth, temperature and fluorescence $\left(\mu \mathrm{g} \mathrm{l}^{-1}\right)$ combined $(73.2 \%)$.

The 3 most abundant species were Synaphobranchus kaupii, Antimora rostrata and Coryphaenoides (Nematonurus) armatus. Data for these are compared with corresponding data from the Porcupine Seabight (PSB; 49 to $51^{\circ} \mathrm{N}$ ) in the NE Atlantic Ocean (Priede et al. 1994).

\section{Synaphobranchus kaupii}

Synaphobranchus kaupii were present at depths $\leq 1934 \mathrm{~m}$ in the southern transect (1), but only to $1124 \mathrm{~m}$ (Transect 2) and $924 \mathrm{~m}$ (Transect 3) in the north. First arrival times ranged from 3 to $24 \mathrm{~min}$, and peak fish numbers within frames (peak frame ${ }^{-1}$ ) ranged between 1 and 7 individuals. The arrival times produced derived abundances of 674 to 12000 eels $\mathrm{km}^{-2}$, which was less than predicted for the PSB (9259 to 37040 eels $\mathrm{km}^{-2}$ ) (Table 3).

There was no significant linear relationship between mean length (mm) and depth (m) for Synaphobranchus kaupii on the MAR $\left(\mathrm{R}^{2}=0.3645, \mathrm{p}>0.1\right.$; Fig. 4). Mean $( \pm$ SD) length was shorter in the PSB $(255 \mathrm{~mm}$, Priede et al. 1994) than on the MAR $(552 \pm 72.9 \mathrm{~mm}$; $\mathrm{n}=137$ ). Maximum biomass was at $1198 \mathrm{~m}$ on the southern transect, where an abundance of 12000 fish $\mathrm{km}^{-2}$ produced an estimate of $1920 \mathrm{~kg} \mathrm{~km}^{-2}$.

\section{Antimora rostrata}

Antimora rostrata were present on the MAR at depths between 924 and $2355 \mathrm{~m}$, with first arrival times of 0 to $2.5 \mathrm{~min}$. The theoretical abundance estimates were 1045 to 82148 fish $\mathrm{km}^{-2}$ (Table 4). The arrival time of $0 \mathrm{~min}$ is excluded because it equates to infinite abundance.

Antimora rostrata on the MAR were much larger $(509 \pm 41.1 \mathrm{~mm} ; \mathrm{n}=417)$ than those found in the PSB ( $346 \mathrm{~mm}$, Priede et al. 1994). Fig. 4 indicates that the relationship between mean length $(\mathrm{mm})$ and depth $(\mathrm{m})$ was insignificant $\left(R^{2}=0.0008, p>0.1\right)$. Estimated biomass was highest at the deepest site where $A$. rostrata were observed (82 $148 \mathrm{~kg} \mathrm{~km}^{-2}$ at $2355 \mathrm{~m}$ ).

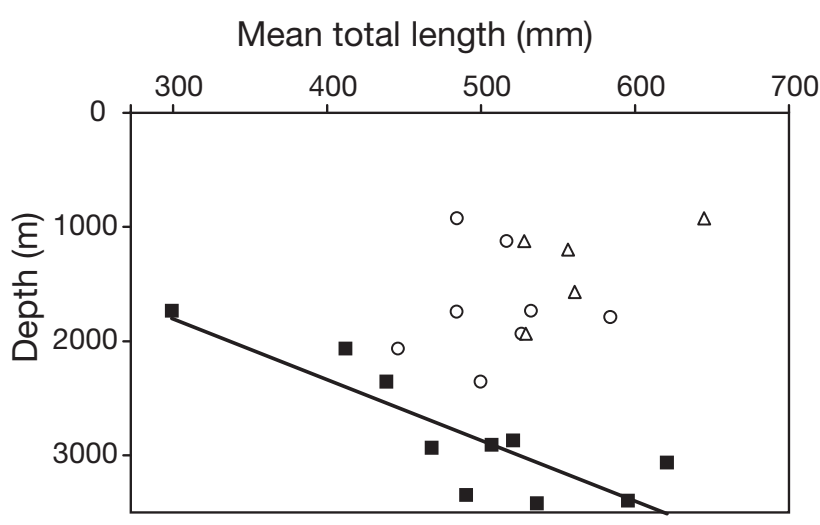

Fig. 4. Relationships of mean total length $(\mathrm{mm})$ with depth $(\mathrm{m})$ for Synaphobranchus kaupii $(\Delta)$, Antimora rostrata (O) and Coryphaenoides (Nematonurus) armatus ( 


\section{Coryphaenoides (Nematonurus) armatus}

Coryphaenoides (Nematonurus) armatus were numerically dominant at the deepest sites, 2869 to $3420 \mathrm{~m}$, with up to 17 individuals simultaneously visible at the bait (Table 2). At shallower sites, 1735 to $2065 \mathrm{~m}(13,15$ \& 16), where Antimora rostrata were also present, first arrival times were considerably slower for $C$. armatus $(22.5,67.5$ and $63.0 \mathrm{~min}$ ) than for $A$. rostrata $(1.5,3.0$ and $6.0 \mathrm{~min})$.

First arrival times ranging between 6 and $81 \mathrm{~min}$ produced abundance estimates of 28 to 2841 fish $\mathrm{km}^{-2}$ (Table 5). When calculating an overall abundance for the MAR using a mean first arrival time of 36 min and a current speed during the first 30 min of

Table 4. Antimora rostrata. Comparison of ROBIO and AUDOS lander data on the MAR and PSB. PSB data from Priede et al. (1994). Total length measured from photographs; wet weight calculated from applying a length-weight regression equation (see 'Materials and methods'). For deployment 14, fish were present from 0 min; hence, no first arrival time is listed

\begin{tabular}{|c|c|c|c|c|c|c|c|c|}
\hline Region & Deployment & $\begin{array}{l}\text { Depth } \\
\text { (m) }\end{array}$ & $\begin{array}{l}\text { First arrival } \\
\text { time (min) }\end{array}$ & $\begin{array}{l}\text { Mean total } \\
\text { length (mm) }\end{array}$ & $\begin{array}{l}\text { Wet weight } \\
(\mathrm{kg})\end{array}$ & $\begin{array}{l}\text { Theoretical abun- } \\
\text { dance (fish } \mathrm{km}^{-2} \text { ) }\end{array}$ & $\begin{array}{l}\text { Biomass } \\
\left(\mathrm{kg} \mathrm{km}^{-2}\right)\end{array}$ & $\begin{array}{l}\text { Peak abun- } \\
\text { dance at bait }\end{array}$ \\
\hline \multirow[t]{10}{*}{ MAR } & 4 & 1934 & 6 & 526 & 1.25 & 5156 & 6445 & 3 \\
\hline & 7 & 1742 & 12 & 484 & 0.94 & 1045 & 982 & 9 \\
\hline & 8 & 924 & 22.5 & 484 & 0.89 & 1071 & 953 & 1 \\
\hline & 10 & 1790 & 1.5 & 584 & 1.87 & 8474 & 15846 & 7 \\
\hline & 13 & 2355 & 1.5 & 500 & 1.00 & 82148 & 82148 & 13 \\
\hline & 14 & 1124 & & 517 & 1.20 & & & 8 \\
\hline & 15 & 1735 & 3 & 533 & 1.25 & 11641 & 14552 & 10 \\
\hline & 16 & 2065 & 6 & 446 & 0.70 & 8477 & 5934 & 7 \\
\hline & Mean & & 8 & $503^{\mathrm{a}}$ & $1.09^{\mathrm{a}}$ & & & \\
\hline & $\mathrm{SD}$ & & 7.13 & 81.61 & 0.64 & & & \\
\hline \multirow[t]{6}{*}{ PSB } & 13 & 1517 & 37 & 183 & 0.029 & 110 & 3 & 2 \\
\hline & 9 & 1650 & 22 & 224 & 0.079 & 306 & 24 & 3 \\
\hline & 16 & 2020 & 9 & 480 & 0.825 & 1829 & 1510 & 3 \\
\hline & 33 & 2501 & 13 & 497 & 1.051 & 876 & 920 & 6 \\
\hline & Mean & & 20 & $267^{a}$ & & & & \\
\hline & $\mathrm{SD}$ & & 12 & 158 & & & & \\
\hline
\end{tabular}

Table 5. Coryphaenoides (Nematonurus) armatus. Comparison of ROBIO and AUDOS lander data on the MAR and PSB. PSB data from Priede et al. (1994). Total lengths were measured from the photographs; wet weights were calculated from applying a length-weight regression equation (see 'Materials and methods')

\begin{tabular}{|c|c|c|c|c|c|c|c|c|c|c|}
\hline \multirow[t]{2}{*}{ Region } & \multirow[t]{2}{*}{ Deployment } & \multirow[t]{2}{*}{$\begin{array}{l}\text { Depth } \\
\text { (m) }\end{array}$} & \multirow{2}{*}{$\begin{array}{l}\text { First arrival } \\
\text { time } \\
(\min )\end{array}$} & \multirow{2}{*}{$\begin{array}{l}\text { Mean total } \\
\text { length } \\
(\mathrm{mm})\end{array}$} & \multirow{2}{*}{$\begin{array}{c}\text { Wet } \\
\text { weight } \\
(\mathrm{kg})\end{array}$} & \multirow{2}{*}{$\begin{array}{l}\text { Theoretical } \\
\text { abundance } \\
\left(\text { fish } \mathrm{km}^{-2} \text { ) }\right.\end{array}$} & \multirow[t]{2}{*}{$\begin{array}{c}\text { Biomass } \\
\left(\mathrm{kg} \mathrm{km}^{-2}\right)\end{array}$} & \multirow{2}{*}{$\begin{array}{c}\text { Peak } \\
\text { abundance } \\
\text { at bait }\end{array}$} & \multicolumn{2}{|c|}{$\begin{array}{l}\text { Constants for } \\
\text { fitted curves }\end{array}$} \\
\hline & & & & & & & & & & $\alpha_{0}$ \\
\hline \multirow[t]{12}{*}{ MAR } & 2 & 3063 & 51.0 & 621 & 1.19 & 71 & 14 & 5 & 250 & 0.050 \\
\hline & 5 & 2869 & 18.0 & 521 & 0.64 & 1119 & 716 & 11 & 205 & 0.100 \\
\hline & 6 & 3346 & 12.0 & 490 & 0.55 & 908 & 500 & 17 & 160 & 0.280 \\
\hline & 9 & 3420 & 24.0 & 536 & 0.81 & 375 & 304 & 6 & 210 & 0.095 \\
\hline & 11 & 3396 & 81.0 & 596 & 1.14 & 28 & 32 & 7 & 95 & 0.110 \\
\hline & 12 & 2908 & 13.5 & 507 & 0.60 & 279 & 167 & 17 & 75 & 0.320 \\
\hline & 13 & 2355 & 22.5 & 439 & 0.39 & 513 & 200 & 7 & 100 & 0.110 \\
\hline & 15 & 1735 & 67.5 & 299 & 0.09 & 36 & 3 & 1 & - & - \\
\hline & 16 & 2065 & 63.0 & 412 & 0.29 & 101 & 29 & 5 & 265 & 0.050 \\
\hline & 17 & 2934 & 6.0 & 468 & 0.47 & 2841 & 1335 & 15 & 80 & 0.250 \\
\hline & Mean & & 36 & $497^{\mathrm{a}}$ & $0.60^{\mathrm{a}}$ & & & & & \\
\hline & $\mathrm{SD}$ & & 27 & 102 & 0.45 & & & & & \\
\hline \multirow[t]{5}{*}{ PSB } & 33 & 2501 & 23.0 & 329 & 0.16 & 280 & 43 & 6 & 185 & 0.10 \\
\hline & 20 & 2897 & 13.0 & 402 & 0.31 & 877 & 274 & 10 & 86 & 0.38 \\
\hline & 26 & 3500 & 16.0 & 442 & 0.57 & 578 & 331 & 10 & 60 & 0.31 \\
\hline & Mean & & 24.0 & $425^{\mathrm{a}}$ & $0.44^{\mathrm{a}}$ & & & & & \\
\hline & SD & & 11 & 112 & 0.41 & & & & & \\
\hline
\end{tabular}


deployments of $0.038 \mathrm{~m} \mathrm{~s}^{-1}$, the abundance estimate is 112 fish $\mathrm{km}^{-2}$.

Coryphaenoides armatus increased in body size with depth (Fig. 4), in accordance with the smaller-shallower trend proposed by Heincke in 1913 (Merrett \& Haedrich 1997) $\left(\mathrm{R}^{2}=0.7251, \mathrm{p}<0.01\right)$. The peak biomass occurred at $2934 \mathrm{~m}$, with an estimated biomass of $1335 \mathrm{~kg} \mathrm{~km}^{-2}$.

The best fits for the arrival rate $\alpha_{0}$ and the staying time $\beta$ are compared with previous data from the PSB (Priede et al. 1994) in Table 5. Comparisons of the MAR (mean $\alpha_{0}=0.15 \pm 0.103$, mean $\beta=160 \pm 75$ ) with the PSB (mean $\alpha_{0}=0.26 \pm 0.146$, mean $\beta=110 \pm 66$ ) indicate that the fish arrive at approximately half the rate of the fish at the PSB, but spend more time at the bait.

\section{DISCUSSION}

This baited photographic survey of the MAR reveals active scavenging fishes present at all latitudes and depths studied. Community structure analysis revealed that, as on slopes around continental margins (Haedrich \& Merrett 1988), the most important determinant of species composition at any given locality is depth.

Species-specific differences in vertical distribution occur: Synaphobranchus kaupii is present at depths $\leq 1934 \mathrm{~m}$, Antimora rostrata at $\leq 2355 \mathrm{~m}$ and Coryphaenoides armatus at $>2000 \mathrm{~m}$. These findings reflect the same sequence observed on the continental margins (Priede 1990, 1991, 1994, Collins et al. 1999, Priede \& Bagley 2000, Henriques et al. 2002), and indicate remarkable species depth fidelity, despite the steep depth gradients that allow for large changes in depth during small horizontal excursions.

At 900 to $1000 \mathrm{~m}$, the crests of the MAR are deeper than the upper limit of the depth distribution of Synaphobranchus kaupii (minimum depth $236 \mathrm{~m}$ ) and Antimora rostrata (minimum depth $350 \mathrm{~m}$ ) (Cohen et al. 1990, Sulak \& Shcherbachev 1997). This truncation in depth range of suitable habitat may influence the populations of these species, whereas Coryphaenoides armatus (minimum depth $1830 \mathrm{~m}$ ) would remain unaffected. For $S$. kaupii, the observed abundances were very low in the north, compared with corresponding data from the PSB at the same latitude. Similarly the maximum depth of occurrence $(1124 \mathrm{~m})$ was much shallower than corresponding observations in the PSB $(2020 \mathrm{~m})$. This is consistent with our initial hypothesis that fishes of the MAR should show a shallower depth range in response to reduced food supply, albeit compounded by an adverse effect of depth range truncation (Cartes \& Carrasson 2004). At the southern tran- sect, the depth range of $\leq 1934 \mathrm{~m}$ and the theoretical abundance exceeding $10000 \mathrm{~km}^{-2}$ are similar to those of the PSB, and may be supported by the proximity of shallower waters around the Azores. Large body size on the MAR, however, is a persistent feature, suggesting that patterns of recruitment and growth are different in mid-ocean populations.

In the southern transect, Antimora rostrata were seen only in Deployment 4, but they were conspicuous by their large numbers and rapid arrival in the north. The peak numbers at the baits in this depth range were significantly higher $(p=0.0036)$ than those found in the PSB (mean $=3.5$ ), and theoretical abundances were also greater (Priede et al. 1994). A. rostrata seem to be very successful on the MAR in the northern part of our study area. This may be linked to the relative lack of success of Synaphobranchus kaupii with which they compete at the upper end of their depth range on the slopes (Priede \& Bagley 2000). No bigger-deeper trend was found in the ROBIO images, but a larger mean total length on the MAR is in agreement with larger individuals being sampled further offshore (Iwamoto 1975, Gordon \& Duncan 1985, Magnusson 2001). Success of A. rostrata on the MAR may be influenced by the fact that there is less commercial fishing activity than on the continental margins, where A. rostrata suffers as bycatch (Devine et al. 2006).

Theoretical abundances for both Synaphobranchus kaupii and Antimora rostrata are speculative. It is worth noting that, due to the inverse square law of the model, short arrival times produce very large abundance estimates that can be subject to large errors. The model also assumes individuals are not gregarious; $S$. kaupii can exhibit shoaling behaviour (Priede et al. 1994).

The theoretical abundances and size of Coryphaenoides armatus on the MAR are comparable with values in the PSB. Previous estimates of the abundance of C. armatus were 104 to 987 ind. $\mathrm{km}^{-2}$ for the PSB and 188 ind. $\mathrm{km}^{-2}$ for Porcupine Abyssal Plain, NE Atlantic, (Priede \& Merrett 1996).

Coryphaenoides armatus shows a significant increase in size with depth. Collins et al. (2005) contend that for scavenging species such as C. armatus selective pressure increases body size with depth, as large individuals are better able to exploit sparsely distributed food packages in the abyss. We observed young macrourids (49 to $113 \mathrm{~mm}$ ) on 4 occasions, but they did not feed directly on bait. Previous brain morphology studies on $C$. armatus indicate that young individuals are visual predators and do not rely on olfactory navigation until they adopt the scavenging habit (>450 mm TL) (Wagner 2003). Hitherto, small fish had not been seen at baited cameras, except for 1 sighting at a cetacean carcass in the PSB, $2710 \mathrm{~m}$ depth (Kemp et al. 
2006). However, observations on the MAR may reflect increased young macrourid abundance, or the attractive (visual and audio) stimuli of other fish in the process of feeding (Bailey \& Priede 2002, Vecchione 2004; available at www.mar-eco.no/sci).

Coryphaenoides armatus are present at bait for longer periods on the MAR than in the PSB (160 vs. $110 \mathrm{~min}$ ) and arrive more slowly (0.15 vs. 0.26 fish $\min ^{-1}$ ). Optimum foraging theory suggests that when food availability is high, populations are denser, and staying time at food patches is short due to other feeding opportunities (Charnov 1976). In agreement primary productivity in the PSB is greater than on the MAR (ca. $90 \mathrm{~g} \mathrm{C} \mathrm{m}^{-2} \mathrm{yr}^{-1}$ vs. $<60 \mathrm{~g} \mathrm{C} \mathrm{m}^{-2} \mathrm{yr}^{-1}$ ) (Berger 1989), with some estimates of $80 \mathrm{~g} \mathrm{C} \mathrm{m}^{-2} \mathrm{yr}^{-1}$ on the northern MAR, down to $<20 \mathrm{~g} \mathrm{C} \mathrm{m}^{-2} \mathrm{yr}^{-1}$ in southern regions (Longhurst 1998).

Estimated abundance for all 3 numerically dominant species and mean species richness decreases at $51^{\circ} \mathrm{N}$, supporting the suggestion that the area is a region of faunal change. Previously established areas of faunal change in the North Atlantic have been very broad, but conclusions were drawn from few data (Merrett 1987, Hareide \& Garnes 2001). The data presented here do not contradict the previously proposed area of 48 to $52^{\circ} \mathrm{N}$ as a region of faunal change (Hareide \& Garnes 2001), but suggest a narrowing in this region to $50-52^{\circ} \mathrm{N}$, coinciding more closely with the position of the sub-polar front in the North Atlantic and the CGFZ.

Baited gears such as ROBIO sample a limited range of species that is attracted to bait mainly via olfactory cues and are complementary to traditional survey techniques. Preliminary MAR-ECO demersal trawl data yielded $>60$ demersal fish species on the MAR (I. Byrkjedal pers. comm.), compared to 22 species visiting ROBIO. Previous studies in the PSB revealed 18 species at a baited lander compared to 71 in trawls (Priede et al. 1994).

Acknowledgements. We thank O. A. Bergstad for inviting us on the 2nd leg of the MAR-ECO cruise, and all the crew of the RV 'G.O. Sars'. We also thank E. Anderson, J. Galbraith, P. Møller and K. Sulak for assistance with species identification and A. Jamieson for technical support. A. Jamieson, K. Kemp, D. Watson and M. Solan are gratefully acknowledged for their comments on earlier drafts. N.J.K. was supported by NERC Grant NER/S/A/2003/11190.

\section{LITERATURE CITED}

Bailey DM, Priede IG (2002) Predicting fish behaviour in response to abyssal food falls. Mar Biol 141:831-840

Berger WH (1989) Appendix: global maps of ocean productivity. In: Berger WH (ed) Productivity of the ocean: present and past. Wiley \& Sons, Chichester, p 429-455

Bergstad OA, Godø OR (2002) The pilot project 'Patterns and processes of the ecosystems of the northern mid-Atlantic': aims, strategy and status. Oceanol Acta 25:219-226

Bray JR, Curtis JT (1957) An ordination of the upland forest communities of southern Wisconsin. Ecol Monogr 27: $325-349$

Carney RS (2005) Zonation of deep-biota on continental margins. Oceanogr Mar Biol Annu Rev 43:211-278

Cartes JE, Carrasson M (2004) Influence of trophic variables on the depth-range distributions and zonation rates of deep-sea megafauna: the case of the western Mediterranean assemblages. Deep-Sea Res Part A 51:263-279

Charnov EL (1976) Optimal foraging, marginal value theorem. Theor Popul Biol 9:129-136

Clarke KR, Warwick RM (1994) Similarity-based testing for community pattern - the 2-way layout with no replication. Mar Biol 118:167-176

Clarke RC, Gorley RN (2001) PRIMER v5: user manual/ tutorial. PRIMER-E, Plymouth

Cohen DM, Inada T, Iwamoto T, Scialabba N (1990) FAO species catalogue, Vol 10. Gadiform fishes of the world (order Gadiformes). FAO Fish Synop 10(125):354

Collins MA, Priede IG, Bagley PM (1999) In situ comparison of activity in two deep-sea scavenging fishes occupying different depth zones. Proc R Soc Lond B 266:2011-2016

Collins MA, Bailey DM, Ruxton GD, Priede IG (2005) Trends in body size across an environmental gradient: a differential response in scavenging and non-scavenging demersal deep-sea fish. Proc R Soc Lond B 272:2051-2057

Devine JA, Baker KD, Haedrich RL (2006) Deep-sea fishes qualify as endangered. Nature 439:29

Gordon JDM, Duncan JAR (1985) The ecology of the deep-sea benthic and benthopelagic fish on the slopes of the Rockall Trough, northeastern Atlantic. Prog Oceanogr 15:37-69

Gordon JDM, Duncan JAR (1987) Deep-sea bottom-living fishes at two repeat stations at 2200 and $2900 \mathrm{~m}$ in the Rockall Trough, northeastern Atlantic Ocean. Mar Biol 96: 309-325

Haedrich RL, Merrett NR (1988) Summary atlas of deep-living demersal fishes in the North Atlantic Basin. J Nat Hist 22: 1325-1362

Hareide NR, Garnes G (2001) The distribution and catch rates of deep water fish along the Mid-Atlantic Ridge from 43 to $61^{\circ}$ N. Fish Res 51:297-310

Henriques C, Priede IG, Bagley PM (2002) Baited camera observations of deep-sea demersal fishes of the northeast Atlantic Ocean at $15-28^{\circ} \mathrm{N}$ off West Africa. Mar Biol 141: 307-314

Iwamoto T (1975) Abyssal fish Antimora rostrata Gunter. Comp Biochem Physiol B 52:7-11

Jamieson AJ, Bagley PM (2005) Biodiversity survey techniques: ROBIO and DOBO landers. Sea Technol 46:52-54

Kemp KM, Jamieson AJ, Bagley PM, McGrath H, Bailey DM, Collins MA, Priede IG (2006) Consumption of large bathyal food fall, a six month study in the north-east Atlantic. Mar Ecol Prog Ser 310:65-76

Longhurst A (1998) Ecological geography of the sea. Academic Press, San Diego

Magnusson JV (2001) Distribution and some other biological parameters of two morid species Lepidion eques (Gunther, 1887) and Antimora rostrata (Gunther, 1878) in Icelandic waters. Fish Res 51:267-281

Merrett NR (1987) A zone of faunal change in the assemblages of abyssal demersal fish in the eastern North Atlantic: a response to seasonality in production. Biol Oceanogr 5:137-151

Merrett NR, Haedrich RL (1997) Deep-sea demersal fish and fisheries. Chapman \& Hall, London 
Priede IG, Bagley PM (2000) In situ studies on deep-sea demersal fishes using autonomous unmanned lander platforms. Oceanogr Mar Biol Annu Rev 38:357-392

Priede IG, Merrett NR (1996) Community studies. 2. Estimation of abundance of abyssal demersal fishes: a comparison of data from trawls and baited cameras. J Fish Biol 49: 207-216

Priede IG, Merrett NR (1998) The relationship between numbers of fish attracted to baited cameras and population density: studies on demersal grenadiers Coryphaenoides (Nematonurus) armatus in the abyssal NE Atlantic Ocean. Fish Res 36:133-137

Priede IG, Smith KL, Armstrong JD (1990) Foraging behavior of abyssal grenadier fish-Inferences from acoustic tagging and tracking in the North Pacific Ocean. Deep-Sea Res Part A Pap 37:81-101

Priede IG, Bagley PM, Armstrong JD, Smith KL, Merrett NR (1991) Direct measurement of active dispersal of food-falls by deep-sea demersal fishes. Nature 351:647-649

Priede IG, Bagley PM, Smith A, Creasey S, Merrett NR (1994) Scavenging deep demersal fishes of the Porcupine Seabight, Northeast Atlantic-Observations by baited camera, trap and trawl. J Mar Biol Assoc UK 74:481-498

Editorial responsibility: Howard I. Browman (Associate Editor-in-Chief), Storebø, Norway
Sulak KJ, Shcherbachev YN (1997) Zoogeography and systematics of six deep-living genera of synaphobranchis eels, with a key to taxa and description of two new species of Ilyophis. Bull Mar Sci 60(3):1158-1194

Troyanovsky FM, Lisovsky SF (1995) Russian (USSR) fisheries research in deep-waters (below $500 \mathrm{~m}$ ) in the North Atlantic. In: Hopper AG (ed) Deep-water fisheries of the North Atlantic oceanic slope. Kluwer, Dordrecht, p 357-365

Uiblein F, Lorance P, Latrouite P (2002) Variation in locomotion behavior in northern cutthroat eel (Synaphobranchus kaupi) on the Bay of Biscay continental slope. Deep-Sea Res I 49:1689-1703

van Weering TCE, McCave IN, Hall IR (1998) Ocean Margin Exchange (OMEX I) benthic processes study-Preface. Prog Oceanogr 42:1-4

Wagner HJ (2003) Volumetric analysis of brain areas indicates a shift in sensory orientation during development in the deep-sea grenadier Coryphaenoides armatus. Mar Biol 142:791-797

Wenner CA, Musick JA (1977) Biology of morid fish Antimora rostrata in western North Atlantic. J Fish Res Board Can $34: 2362-2368$

Submitted: November 29, 2005; Accepted: February 23, 2006 Proofs received from author(s): July 28, 2006 